\title{
PENGARUH LEVERAGE, EARNING POWER, DAN KEPEMILIKAN MANAJERIAL TERHADAP MANAJEMEN LABA
}

\author{
Mishelei Loen \\ Fakultas Ekonomi Universitas Krisnadwipayana \\ Jalan Unkris Jatiwaringin Jakarta Timur \\ mishelei.loen@gmail.com
}

\begin{abstract}
The purpose of the reasearch to find out and analyze the effect of Leverage, Earning Power, and Managerial Ownership of Earnings Management, Study on Companies Conducting Right Issues on the Indonesia Stock Exchange for the period 2016-2020. The analytical method used in this study namely by using descriptive statistical methods and multiple regression then using classical assumption and hypothesis testing using $T$ test, $F$ test and $R^{2}$ test, sampling using purposive sampling method with a population of 55 from the population obtained 18 samples. The results showed that partially or according to the results of the T test, that Leverage, Earning Power, and Managerial Ownership have a significant effect on Study Management in Companies Conducting Right Issues on the Indonesia Stock Exchange for the 2016-2020 period.
\end{abstract}

Keywords : Leverage, Earning Power, Ownership Managerial, Earnings Management

\section{PENDAHULUAN}

Salah satu fenomena yang terjadi dalam sektor akuntansi adalah tentang praktek manajemen laba. Banyak perusahaan yang melakukan kegiatan memanipulasi laporan keuangan mereka dengan alasan yang berbeda. Laporan keuangan adalah alat yang sangat berguna bagi suatu perusahaan, misalnya dapat digunakan untuk menarik investor dan mengajukan peminjaman melalui bank. Alasan dan tehnik dilakukannya praktek manajemen laba didasarkan pada tujuan manajemen Bassiouny (2016). Manajemen laba adalah adanya asimetri informasi dan kecenderungan dari pihak eksternal yang lebih memprioritaskan informasi laba membuat manajemen mengambil tindakan untuk membuat laporan keuangan terlihat baik demi kepentingan diri sendiri. Tindakan manajemen laba menarik untuk dilakukan penelitian karena akan memberikan gambaran terkait dengan perilaku manajemen dalam melakukan pelaporan aktivitas usahanya pada periode tertentu dan kemungkinan adanya keinginan pelaku dalam perusahaan untuk memanajemen laporan keuangannya. Pada penelitian yang dilakukan oleh Sudiyanto (2005), manajemen laba tidak harus selalu dihubungkan dengan tindakan memanipulasi data atau informasi akuntansi tetapi lebih mengarah kepada pemilihan metode (accounting method) untuk mengelola keuntungan karena memang diizinkan menurut accounting regulation. Adanya manajemen laba dalam penyusunan laporan keuangan dianggap sebagai suatu tindakan yang rasional karena memanfaatkan fleksibilitas dalam ketentuan pelaporan keuangan, namun tetap harus memperhatikan kaidah-kaidah dari metode Akuntansi.

Leverage adalah pemanfaatan sumber dana serta aset perusahaan yang memiliki biaya tetap, penggunaan sumber daya dan aset tersebut bertujuan untuk meningkatkan potensi keuntungan (Sartono, 2008). Leverage dalam penelitian ini diproksikan dalam bentuk rasio Debt to Asset. Penggunaan rasio tersebut akan memberikan gambaran perbandingan dari utang perusahaan yang kemungkinan mempunyai resiko dalam pengembalian serta akan berpengaruh terhadap laba 
perusahaan. Dengan demikian, dapat ditunjukkan bahwa semakin tinggi nilai utang yang dimiliki oleh perusahaan, maka akan menyebabkan semakin banyak tindakan manajemen dilakukan. Hal tersebut dikarenakan perusahaan dengan tingkat utang yang tinggi akan dinilai mempunyai resiko kebangkrutan yang besar sehingga perusahaan kemungkinan akan memanajemen labanya agar tidak berdampak buruk terhadap citra perusahaan dimata para investor.

Salah satu bagian yang digunakan oleh pihak eksternal dalam menilai suatu perusahaan adalah kemampuan perusahaan tersebut dalam memperoleh laba atau dapat disebut dengan earning power. Tingginya perilaku earning power menyebabkan semakin meningkatnya tindakan manajemen laba yang dilakukan oleh perusahaan karena earning power dimanfaatkan oleh para investor dalam penilaian efisiensi perusahaan dalam memperoleh labanya, serta dijadikan motivasi oleh pihak perusahaan dalam melakukan praktik manajemen laba guna memberikan keuntungan pribadi serta meningkatkan nilai perusahaannya.

Diyah dan Erman (2009), dalam Sudiyanto (2016) mengartikan bahwasanya kepemilikan manajerial adalah proporsi pemegang saham dari pihak manajemen yang secara aktif ikut dalam pengambilan keputusan perusahaan. Menurut Utami (2016) kepemilikan manajerial berpengaruh positif terhadap manajemen laba. Sedangkan menurut Sudiyanto (2016), kepemilikan manajerial tidak berpengaruh signifikan terhadap manajemen laba.

Menurut teori keagenan, perbedaan kepentingan antara pihak manajer dan pemegang saham dapat menimbulkan perselisihan yang disebut agency conflict, karena dengan adanya konflik keagenan yang timbul akibat pemisahan tugas antara agen dan prinsipal membuat mereka mengutamakan kepentingan utilitasnya masing-masing. Perusahaan menyerahkan tanggung jawab yang dimilikinya kepada manajemen agar manajemen menjalankan fungsi serta perannya untuk mengelola operasional perusahaan Natalia (2013). Adanya kepemilikan manejerial diharapkan mampu membuat agen dan prinsipal memiliki tujuan yang selaras dan harmonis. Dengan adanya kepemilikan saham oleh manajer dalam perusahaan akan mengoptimalkan kinerja dari manajemen perusahaan serta memberikan motivasi dalam bertindak hati-hati, sehingga akan mengurangi praktik manajemen laba. Hal ini dikarenakan setiap pengambilan keputusan yang diambil oleh manajemen perusahaan akan berdampak juga kepada mereka sebab selain menjadi manajemen, mereka juga ikut andil bagian sebagai investor.

Penelitian ini ditujukan untuk membuktikan faktor-faktor yang mempengaruhi manajemen untuk melakukan praktik manajemen laba (earnings management), terutama ketika perusahaan melakukan (right issue) melakukan penawaran saham terbatas kepada para pemegang saham lama, karena dari beberapa penelitian yang meneliti ketika perusahaan melakukan penawaran saham kepada publik (selain right issue) terdapat perbedaan earning management dari sebelum dan sesudah perusahaan melakukan penawaran saham kepada publik. Perusahaan yang melangsungkan right issue memiliki beberapa target yaitu, melakukan ekspansi usaha, membayar utang, melakukan merger, melakukan akuisisi perusahaan, dan sebagainya. Objek dalam penelitian ini adalah perusahaanperusahaan yang listing di Bursa Efek Indonesia (BEI) yang melakukan kebijakan aksi korporasi hak memesan efek terlebih dahulu atau right issue. Pada tahun 2016 sampai dengan tahun 2020 ada sebanyak 55 perusahaan yang mengeluarkan kebijakan right issue. Atas dasar uraian tersebut permasalahan dalam penelitian ini adalah Apakah Leverage berpengaruh terhadap manajemen laba, Apakah Earning Power berpengaruh terhadap manajemen laba, dan Apakah Kepemilikan Manajerial 
berpengaruh terhadap manajemen laba.

\section{LANDASAN TEORI}

\section{Agency Theory}

\section{Keagenan menjelaskan mengenai} konflik antara pemilik perusahaan (principal) dengan pengelola perusahaan (agent) Sulistiyanto (2008). "Manajer yang merupakan pengelola perusahaan tentu memiliki kepentingan untuk memaksimalkan kesejahteraannya sendiri. Disisi lain, manajer juga memiliki kewajiban dalam menjalankan tugasnya untuk memaksimalkan kesejahteraan para pemilik perusahaan (principal) baik dalam jangka pendek maupun jangka panjang. Adanya perbedaan tujuan serta pemisahan antara kepemilikan dan pengelolaan perusahaan tersebut menyebabkan manajer dapat bertindak sesuai keinginan mereka sendiri tanpa memperhatikan kepentingan principal. Teori agensi juga mengasumsikan adanya asimetri informasi, yaitu dimana agen yang mengelola perusahaan memiliki lebih banyak informasi internal perusahaan daripada prinsipal."Adanya konflik kepentingan dan asimetri informasi itulah yang mendorong manajer (agen) menyajikan informasi yang tidak sebenarnya kepada pemilik (principal). Sulistiyanto (2008) mengemukakan bahwa "upaya manajer untuk mengubah, menyembunyikan dan merekayasa angka-angka dalam laporan keuangan dengan mempermain-kan metode dan prosedur akuntansi yang digunakan perusahaan sering disebut sebagai manajemen laba"

\section{Manajemen Laba}

Manajemen laba merupakan campur tangan manajemen dalam proses penyusunan laporan keuangan yang tujuannya untuk dilaporkan kepada pihak eksternal dengan motivasi tertentu. Manajemen laba dapat mengurangi kredibilitas dari laporan keuangan karena tidak memcerminkan kondisi perusahaan yang sesungguhnya. Para pemakai laporan keuangan dimungkinkan akan mengambil keputusan yang salah dikarenakan mereka memperoleh informasi keuangan yang salah"(Naftalia dan Marsono, 2013. Manajemen laba adalah upaya untuk mengubah, menyembunyikan, dan menunda informasi keuangan Sulistyanto (2008).

\section{Leverage}

Kasmir (2019) menyatakan bahwa semakin besar rasio leverage, berarti semakin tinggi nilai utang perusahaan. Leverage merupakan rasio yang digunakan untuk mengukur sejauh mana aktiva perusahaan dibiayai dengan utang. Artinya berapa besar beban utang yang ditanggung perusahaan dibandingkan dengan aktivanya. Dalam arti luas dikatakan bahwa leverage digunakan untuk mengukur kemampuan perusahaan untuk membayar seluruh kewajibannya, baik jangka pendek maupun jangka panjang apabila perusahaan dibubarkan (dilikuidasi)

\section{Earning Power}

Riyanto (2008), mengatakan Earning Power adalah kemampuan untuk mengetahui efisiensi perusahaan dengan melihat besar kecilnya dalam menghasilkan laba. Dengan melakukan analisis terhadap rasio profitabilitas perusahaan maka investor dapat menilai kemampuan perusahaan dalam menghasilkan laba (Earning Power) dan sejauh mana efektifitas pengelolaan perusahaan pada masa - masa yang lalu.

\section{Kepemilikan Manajerial}

Sudiyanto (2016) menjelaskan bahwa kepemilikan manajemen adalah proporsi pemegang saham dari pihak manajemen yang secara aktif ikut dalam pengambilan keputusan perusahaan 
(Direktur dan Dewan Komisaris). Ketika kepemilikan saham oleh manajemen rendah maka ada kecenderungan akan terjadinya perilaku opportunistic manajer yang meningkat. Dengan adanya kepemilikan terhadap saham perusahaan, maka dipandang dapat menyelaraskan potensi perbedaan kepentingan antara manajemen dan pemegang saham lainnya sehingga permasalahan antara agen dan prinsipal diasumsikan akan hilang apabila seorang manajer juga sekaligus sebagai pemegang saham.

\section{Pengembangan Hipotesis}

\section{Pengaruh Leverage Terhadap Manajemen Laba}

Utami (2016), didalam penelitiannya menunjukan bahwa variabel leverage berpengaruh terhadap manajemen laba. Perusahaan tidak dapat memenuhi kewajiban membayar utang pada waktunya sehingga diduga melakukan hal tersebut karena terancam default. Sesuai dengan penelitian Almadara, (2017) dan Perdana (2012) yang menyatakan bahwaLeverage berpengaruh positif dan signifikan terhadap manajemen laba karena leverage menjadi salah satu faktor yang berpengaruh terhadap praktik manajemen laba karena manajemen laba berkaitan dengan sumber dana eksternal khususnya utang yang digunakan untuk membiayai kelangsungan operasi perusahaan kedepannya. Hipotesis yang diajukan :

$\mathrm{H}_{1}$ : Leverage berpengaruh positif dan signifikan terhadap manajemen laba

\section{Pengaruh Earning Power terhadap manajemen laba}

Purnomo dan Pratiwi (2009), dalam penelitiannya berhasil membuktikan bahwa kemampuan menghasilkan laba suatu perusahaan dapat mendorong pihak manajemen untuk melakukan modifikasi laba baik dengan cara income increasing accrual ataupun income decreasing accrual. Akan tetapi teknik yang digunakan untuk melakukan praktek tersebut tergantung pada motivasi dari pihak manajemen perusahaan. Sesuai dengan penelitian Insani (2017) yang menyatakan bahwa earnings power berpengaruh positif signifikan terhadap manajemen laba pada perusahaan yang terdaftar di BEI pada tahun 2011-2015. Hipotesis yang diajukan: $\mathrm{H}_{2}$ : Earning Power berpengaruh positif dan signifikan terhadap manajemen laba

\section{Pengaruh Kepemilikan Manajerial terhadap Manajemen Laba}

Menurut Utami (2016), mengatakan dalam penelitiannya memiliki hasil bahwa kepemilikan manajerial berpengaruh positif terhadap manajemen laba. Ini dikarenakan seorang manajer yang juga mempunyai saham memiliki kepentingan pribadi yaitu adanya return yang diperoleh dari kepemilikan sahamnya yang ada di perusahaan. Hipotesis yang diajukan hipotesis:

H3: Kepemilikan Manajerial berpengaruh positif dan signifikan terhadap manajamen laba

\section{METODE PENELITIAN}

\section{Desain Penelitian}

Jenis data yang digunakan maka penelitian ini data sekunder dengan pendekatan kuantitatif. Data sekunder yang digunakan merupakan data dari perusahaan yang terdaftar dalam Bursa Efek Indonesia pada tahun 2016 sampai dengan tahun 2020. Pada penelitian ini, digunakan tiga variabel bebas (independent variable), satu variabel terikat (dependent variable). Adapun variabel independen yang digunakan dalam penelitian ini yaitu Leverage, Earning Power dan Kepemilikan Manajerial. Sedangkan variabel dependen yang digunakan dalam penelitian ini yaitu Manajemen Laba. 
Tabel 1. Indikator Penelitian

\begin{tabular}{|c|c|c|}
\hline Variabel & Indikator & Skala \\
\hline $\begin{array}{l}\text { Leverage } \\
(X 1)\end{array}$ & $\frac{\text { Total Debt }}{\text { Total Assets }}$ & Rasio \\
\hline $\begin{array}{l}\text { Earning } \\
\text { Power }(X 2)\end{array}$ & $\frac{\text { Net Income After Tax }}{\text { Total Revenue }}$ & Rasio \\
\hline $\begin{array}{l}\text { Kepemilika } \\
\mathrm{n} \\
\text { Manajerial } \\
(\mathrm{X} 3)\end{array}$ & $\frac{\text { Total Saham Manajemen }}{\frac{\text { Perusahaan }}{\text { Total Saham yang beredar }}}$ & Rasio \\
\hline $\begin{array}{l}\text { Manajemen } \\
\text { Laba (Y) }\end{array}$ & $\begin{array}{l}\text { Modified Jones Models / } \\
\text { Discretionary Accrual }\end{array}$ & Rasio \\
\hline
\end{tabular}

\section{Populasi dan Sampel}

Pada penelitian ini, obyek yang akan diteliti adalah perusahaan yang melakukan Right Issue atau aksi korporasi HMETD (Hak Memesan Efek Terlebih Dahulu) yang terdaftar di Bursa Efek Indonesia. Penelitian ini menggunakan periode penelitian tahun 2016 sampai dengan tahun 2020 yang terdapat dalam perusahaan yang terdaftar dalam Bursa Efek Indonesia. Populasi yang dijadikan objek penelitian ini adalah sebanyak 55 perusahaan yang terdaftar dan melakukan right issue. Penarikan sampel dilakukan dengan menggunakan metode Purposive Sampling, dengan tujuan mendapatkan sampel yang sesuai dengan kriteria yang telah ditentukan antara lain: Perusahaan yang melakukan Right Issue di Bursa Efek Indonesia untuk tahun 2016-2020, Perusahaan Sektor Manufaktur, Jasa, dan Dagang yang terdaftar di Bursa Efek Indonesia, Laporan Keuangan disajikan dalam mata uang rupiah, Perusahaan harus memiliki data Kepemilikan Manajerial, dan Perusahaan yang menerbitkan Laporan Keuangan yang lengkap selama periode pengamatan. Berdasarkan kriteria- kriteria tersebut diperoleh sampel sebanyak 18 perusahaan.
HASIL PENELITIAN

DAN

\section{PEMBAHASAN}

\section{Uji Statistik Deskriptif}

Analisis statistik deskriptif merupakan gambaran atau deskripsi data berdasarkan nilai rata-rata (mean), standar deviasi, nilai maksimum, dan minimum dari variabel levarage, earning power, kepemilikan manajerial dan manajemen laba. Hasil analisis statistik deskriptif dengan menggunakan SPSS 25.0 dari variabel-variabel penelitian sebagai berikut:

Tabel 2. Uji Statistik Deskriptif

\begin{tabular}{|c|c|c|c|c|}
\hline & $\begin{array}{l}\text { Minimu } \\
\mathrm{Nm}\end{array}$ & $\begin{array}{l}\text { Maximu } \\
\mathrm{m}\end{array}$ & $\begin{array}{l}\text { Mea } \\
\mathrm{n}\end{array}$ & $\begin{array}{l}\text { Std. } \\
\text { Deviation }\end{array}$ \\
\hline everage & $\begin{array}{l}9 \\
0,13\end{array}$ & ,92 &, 55 & 238544227, \\
\hline $\begin{array}{l}\text { Earning } \\
\text { ower }\end{array}$ & $\begin{array}{ll}9 \\
0^{-, 14}\end{array}$ & ,71 & ,18 & 139340538 \\
\hline Cepemilika & $\begin{array}{l}9 \\
0\end{array}$ & 4,60 & ,41 & $\begin{array}{l}1,12755201 \\
5\end{array}$ \\
\hline $\begin{array}{l}\text { Manajemen } \\
\text { aba }\end{array}$ & $\begin{array}{l}9 \\
0\end{array}-2,23$ & 2,14 &, 06 & $\begin{array}{l}0,52004823 \\
9\end{array}$ \\
\hline
\end{tabular}

\section{Uji Normalitas}

Tabel 3. Uji Normalitas

One-Sample Kolmogorov-Smirnov Test

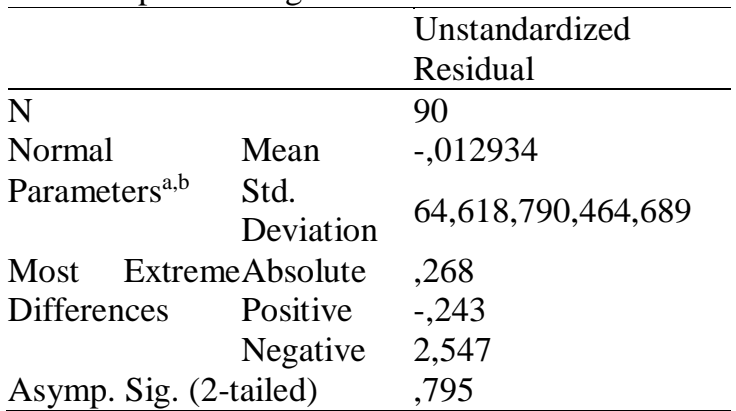

Berdasarkan tabel 3 menunjukan bahwa hasil Uji Kolmogrov-Smirnov Asymp. Sig. (2-tailed) sebesar 0.795 dan jika hasil > 0,05 berarti model regresi berdistribusi normal dan jika hasil $<0,05$ berarti model regresi tidak berdistribusi normal. Artinya dari hasil tersebut diatas dapat disimpulkan bahwa model regresi ini berdistribusi normal dan telah memenuhi asumsi normalitas. 


\section{Hasil Uji Asumsi Klasik}

\section{Uji Multikolinierritas}

Uji dilakukan dengan bantuan SPSS. Tidak adanya multikolinearitas dapat diketahui jika nilai VIF $<10$ dan nilai tolerance $\geq 0,1$. Diperoleh Leverage sebesar 0,843, Earning sebesar 0,847, Kepemilikan Manajerial sebesar 0,82 yang artinya lebih besar dari 0,10. Dan memperoleh nilai VIF pada variabel Leverage sebesar 1,186, Earning sebesar 1,181, Kepemilikan Manajerial sebesar 1,22 yang artinya juga lebih kecil dari 10 maka dapat di simpulkan bahwa data penelitian ini tidak terjadi Multikolinearitas.

Tabel 4. Uji Multikolinearitas

\begin{tabular}{|c|c|c|}
\hline \multirow[b]{2}{*}{ Model } & \multicolumn{2}{|c|}{ Collinearity Statistics } \\
\hline & Tolerance & VIF \\
\hline \multicolumn{3}{|l|}{1 (Constant) } \\
\hline Leverage & 843 & 1,186 \\
\hline Earning Power & 847 & 1,181 \\
\hline \multicolumn{2}{|c|}{ Kepemilikan Manajerial,82 } & 1,22 \\
\hline
\end{tabular}

\section{Uji Autokorelasi}

Tabel 5.Uji Autokorelasi

\begin{tabular}{ll}
\hline Model & Durbin-Watson \\
\hline 1 & 1,519
\end{tabular}

Dapat disimpulkan bahwa jika probalititas nilai Durbin-Watson berada di angka antara -2 dan +2 dinyatakan tidak terjadi autokorelasi. Pada tabel 5 menunjukan bahwa nilai Durbin-Watson yaitu 1,519, maka disimpulkan bahwa model ini tidak terjadi autokorelasi.

\section{Uji Heteroskedastisitas}

Pengujian asumsi heteroskedastisitas diharapkan residual memiliki ragam yang homogen. Pengujian asumsi heterokedastisitas dapat dilihat melalui Scatter Plot. Hasil pengujian asumsi heteroskedastisitas menggunakan scatter plot dapat diketahui bahwa titik-titik residual yang dihasilkan oleh kedua model menyebar secara acak. Dengan demikian asumsi heteroskedastisitas terpenuhi.

\section{Hasil Analisis Regresi Berganda}

Table 6. Uji Analisis Berganda

\begin{tabular}{|c|c|c|}
\hline \multirow[b]{2}{*}{ Model } & \multicolumn{2}{|c|}{$\begin{array}{l}\text { Unstandardized } \\
\text { Coefficients }\end{array}$} \\
\hline & $\mathrm{B}$ & Std. Error \\
\hline $\begin{array}{ll}1 & \text { (Constant) }\end{array}$ & 6,178 & 1,872 \\
\hline Leverage & 1,79 & 1,321 \\
\hline Earning Power & 1,85 & 1,544 \\
\hline $\begin{array}{l}\text { Kepemilikan } \\
\text { Manajerial }\end{array}$ & 3,66 & 2,14 \\
\hline
\end{tabular}

Koefisien persamaan linier diatas dapat dijelaskan bahwa koefisien regresi untuk konstan sebesar 6.178 hal ini menunjukan bahwa Leverage, Earning dan Kepemilikan Manajerial maka Manajemen Laba yang mungkin akan terjadi sebesar 6,178 .

Koefisien untuk variabel Leverage nilai koefisien regresi pada Leverage bertanda positif sebesar 1.79 dengan demikian dapat disimpulkan bahwa variabel Leverage berpengaruh positif terhadap Manajemen Laba.

Koefisien untuk variabel Earning nilai koefisien pada Earning bertanda positif sebesar 1,85 dengan demikian dapat disimpulkan bahwa variabel Earning berpengaruh positif terhadap Manajemen Laba.

Koefisien untuk variabel Kepemilikan Manajemen nilai koefisien pada Kepemilikan Manajemen bertanda positif sebesar 3.66 dengan demikian dapat disimpulkan bahwa variabel Kepemilikan Manajemen berpengaruh positif terhadap Manajemen Laba.

\section{Uji Determinasi $\left(\mathbf{R}^{2}\right)$.}

Koefisien determinasi digunakan untuk mengetahui kemampuan variabel independen dalam menjelaskan variabel dependen. Nilai yang ditentukan dapat dilihat dari nilai Adjusted $R$-squared. 
Berikut ini berdasarkan hasil data melalui program SPSS sebagai berikut.

Tabel 7. Uji R ${ }^{2}$

\begin{tabular}{lll}
\hline ModelR & R SquareAdjusted R Square \\
\hline $1 \quad 853^{\mathrm{a}}, 727 \quad, 707$
\end{tabular}

Berdasarkan hasil uji $\mathrm{R}^{2}$ yang telah disajikan dalam tabel diatas menjelaskan bahwa nilai $\mathrm{R}^{2}$ sebesar 0.727 . Hal tersebut dinyatakan bahwa pengaruh variabel Leverage, Earning dan Kepemilikan Manajemen secara simultan terhadap variabel Manajemen Laba sebesar 72,7 \% sedangkan sisanya yang sebesar $27,3 \%$ dipengaruhi oleh variabel yang tidak diteliti.

\section{Pembahasan Hasil Penelitian}

\section{Pengaruh Leverage terhadap Manajemen Laba}

Dari hasil pengujian (Uji-t) secara parsial dengan diperoleh nilai $\mathrm{t}$ hitung $=$ $3,843>\mathrm{t}$ tabel $=1,662$ dan nilai signifikansi nya sebesar 0,001 yang berarti menunjukan nilai $<0,05$ dengan demikian H1 diterima sehingga dapat disimpulkan bahwa Leverage berpengaruh signifikan terhadap Manajemen Laba. Hasil penelitian tersebut mengindikasikan bahwa tingginya Leverage suatu perusahaan yang ditandai dengan tingginya tingkat utang mengakibatkan pihak manajemen menjadi lebih sulit untuk memprediksi masa depan perusahaan. Kreditor akan melakukan pengawasan yang lebih ketat ketika perusahaan memiliki utang yang tinggi. Hal tersebut mengakibatkan berkurangnya fleksibelitas pihak manajemen untuk melakukan Manajemen Laba, sehingga semakin tinggi Leverage maka Manajemen Laba yang dilakukan pihak manajemen akan semakin rendah. Begitu juga sebaliknya, ketika Leverage rendah maka Manajemen Laba yang dilakukan oleh pihak manajemen akan semakin tinggi. Hasil penelitian ini sama dengan hasil penelitian yang dilakukan oleh Utami
(2016) yang menyatakan bahwa Leverage berpengaruh positif terhadap Manajemen Laba.

\section{Pengaruh Earning terhadap Manajemen Laba}

Dari hasil pengujian (Uji-t) secara parsial dengan diperoleh nilai $\mathrm{t}$ hitung $=$ $3,411>\mathrm{t}$ tabel $=1,662$ dengan nilai signifikansi sebasar 0,001 yang berarti menunjukan nilai $<0,05$ sehingga dapat disimpulkan bahwa $\mathrm{H} 2$ diterima. Hal ini berarti variabel Earning secara parsial berpengaruh signifikan terhadap Manajemen Laba. Pengaruh Earning berdasarkan Right Issue terhadap Praktik Manajemen Laba mempunyai hubungan (korelasi) yang erat serta searah atau positif hal ini berarti apabila terjadi kenaikan pada Earning perusahaan akan diikuti dengan kenaikan nilai DAC, begitu pula sebaliknya jika terjadi penurunan Earning akan terjadi penurunan DAC pula. Oleh karena itu hipotesis penulis dapat diterima. Hasil penelitian ini sama dengan hasil penelitian yang dilakukan oleh Khairatul Insani (2017) yang menyatakan bahwa Earning berpengaruh positif terhadap Manajemen Laba.

\section{Pengaruh Kepemilikan Manajerial terhadap Manajemen Laba}

Dari hasil pengujian (Uji-t) secara parsial dengan diperoleh nilai $\mathrm{t}$ hitung $=$ $2,82>\mathrm{t}$ tabel $=1,662$ dengan nilai signifikansi sebasar 0,02 yang berarti menunjukan nilai $<0,05$ sehingga dapat disimpulkan bahwa $\mathrm{H} 3$ diterima artinya variabel Kepemilikan Manajemen secara parsial berpengaruh signifikan terhadap Manajemen Laba. Dapat diartikan bahwa semakin tinggi kepemilikan manajerial maka tindakan manajemen laba akan semakin berkurang atau sebaliknya. Hasil penelitian ini selaras dengan hasil penelitian yang dilakukan oleh Hamid (2015) yang menyatakan bahwa kepemilikan manajerial berpengaruh 
signifikan terhadap manajemen laba. Hasil penelitian ini tidak selaras dengan hasil penelitian Rahyuningsih dan Ayem (2020) yang menyatakan bahwa kepemilikan manajerial tidak memiliki pengaruh terhadap manajemen laba.

Adanya kepemilikan manajerial akan membuat posisi manajemen sama dengan pemilik perusahaan yang dapat menyelaraskan atau menyatukan kepentingan manajemen dengan pemegang saham sehingga manajemen akan bertindak sama seperti investor pada umumnya dan tidak akan melakukan manajemen laba agar dapat mengetahui keadaan perusahaan yang terjadi sesungguhnya.

\section{KESIMPULAN DAN SARAN}

\section{Kesimpulan}

Berdasarkan hasil penelitian dan pembahasan yang telah dilakukan menghasilkan beberapa kesimpulan yang dapat ditarik sebagai berikut: (1) Leverage berpengaruh terhadap manajemen laba, (2) Earning Power berpengaruh terhadap manajemen laba, dan Kepemilikan Manajerial berpengaruh terhadap manajemen laba.

\section{Saran}

Berdasarkan hasil penelitian mengenai pengaruah antara Leverage, Earning Power, dan Kepemilikan Manajerial terhadap Manajemen Laba (Studi kasus pada Perusahaan yang melakukan Right Issue di Bursa Efek Indonesia untuk tahun 2016-2020), penulis memberikan saran sebagai berikut : (1) Bagi investor maupun calon investor agar dapat berhati-hati dalam memperhatikan nilai Leverage, Earning Power dan Kepemilikan Manajerial agar dapat membuat keputusan yang baik untuk berinvestasi (2) Bagi pihak manajemen perusahaan agar penelitian ini dapat digunakan sebagai pertimbangan dalam mengambil keputusan manajemen sehingga mengurangi terjadinya praktik manajemen laba. (3) Bagi peneliti selanjutnya agar dapat menambah jumlah variabel yang berpengaruh terhadap Manajemen Laba, kemudian disarankan juga agar dapat menambah periode pengamatan.

\section{DAFTAR PUSTAKA}

Alkindo Naratama Tbk PT https://www.idx.co.id/perusahaantercatat/profil-perusahaantercatat/detail-profile-perusahaantercatat $/$ ?kodeEmiten $=$ ALDO

Almadara, H. U. (2017). Pengaruh Leverage Terhadap Manajemen Laba Dengan Corporate Governance Sebagai Variabel Moderasi Pada Perusahaan Perbankan Yang Terdaftar Di Bei Bei. Skripsi, i-132.

Aneka Tambang Tbk PT https://www.idx.co.id/perusahaantercatat/profil-perusahaantercatat/detail-profile-perusahaantercatat/?kodeEmiten=ANTAM

Arthawan, P. T., \& Wirasedana, W. P. (2018). Pengaruh Kepemilikan Manajerial, Kebijakan Utang Dan Ukuran Perusahaan Terhadap Manajemen Laba. E-Jurnal Akuntansi, 22 , https://doi.org/10.24843/eja.2018.v22. i01.p01

Augustine, D. Y., \& Dwianika, A. (2019). Earnings Management In Indonesia: Determinant of Company Size, Structure Of Managerial Ownership And Profitability On Earnings Management With Asymmetry Information And Green Intellectual Capital As Moderating Variables. South East Asia Journal of Contemporary Business, Economics and Law, 19(5), 176-188.

Alexander, N., \& Hengky, H. (2017). Factors Affecting Earnings Management in the Indonesian Stock Exchange. GATR Journal of Finance 
and Banking Review, 2(2), 08-14. https://doi.org/10.35609/jfbr.2017.2.2( 2)

Bank Woori Saudara Tbk PT https://www.idx.co.id/perusahaantercatat/profil-perusahaantercatat/detail-profile-perusahaantercatat/?kodeEmiten=SDRA

Belkaoui, Ahmed Riohi. (2004). Accounting Theory. Jakarta: Salemba Empat

Berlina Tbk PT

https://www.idx.co.id/perusahaantercatat/profil-perusahaantercatat/detail-profile-perusahaan tercatat $/$ ?kodeEmiten $=$ BRNA

Bodie, K. A. (2016). Investasi, Alih Bahasa oleh Zuliani Dalimunthe dan Budi Wibowo. Jakarta: Salemba Empat

Burhan, Bungin. (2006). Analisis Data Penelitian Kualitatif. Jakarta : Raja Grafindo

Cruthchley, C. E., dan R. S. Hansen. (1989). "A test of Agency Theory of Maagerial Ownership, Corporate Leverage, and Corporate Dividends." Financial Management. Winter: hal. 36.

Faizal, Achmad. (2014). "Pengaruh Kebijakan Dividen, Struktur Kepemilikan dan Biaya Agensi terhadap Harga Saham”. Jurnal Bisnis dan Akuntansi.

Healy, P.M. and Wahlen, J.M. (1999) "A Review of the Earnings Management Literature and Its Implications for Standard Setting". Accounting Horizons, 13, 365-383.

Hery. (2015). Analisis Laporan Keuangan. Edisi 1. Yogyakarta: Center For Academic Publishing Services. Ikatan Akuntan Indonesia.

Hotel Mandarin Regency Tbk PT https://www.idx.co.id/perusahaantercatat/profil-perusahaantercatat/detail-profile-perusahaantercatat/?kodeEmiten=HOME

Ikatan Akuntan Indonesia (IAI). 2015. Penyajian Laporan Keuangan. Pernyataan Standar Akuntansi Keuangan (PSAK) No. 1 (Revisi
2015). DSAK-IAI. Jakarta.

Insani, Khairatul. (2017). "Pengaruh Earnings Power dan Ukuran Perusahaan Terhadap Manajemen Laba (Studi Empiris pada Perusahaan Manufaktur yang Terdaftar di BEI tahun 2011-2015)". Jurnal Akuntansi, Vol 5, No 1.

Jensen, Michael C. dan W.H. Meckling. (1976). "Theory of The Firm: Managerial Behavior, Agency Cost and Ownership Structure". Journal of Financial Economics, 3. Hal 305- 360.

Jones, Jennifer J. (1991). "Earnings Management During Import Relief Investigations". Journal Of Accounting Research, Vol 29, No.2 1991, p.193228.

Kasmir. (2019). Analisis Laporan Keuangan. Edisi Pertama. Cetakan Keduabelas. Jakarta: PT Raja Grafindo Persada

Klein, A. (2002). "Audit Committee, Board of Directors Characteristics and earnings Management". Journal of Accounting and Economics, 33, Hal. 375-400.

Krakatau Steel Tbk PT https://www.idx.co.id/perusahaantercatat/profil-perusahaantercatat/detail-profile-perusahaantercatat/?kodeEmiten=KRAS

Logindo Samudra Makmur Tbk PT https://www.idx.co.id/perusahaantercatat/profil-perusahaantercatat/detail-profile-perusahaantercatat $/$ kodeEmiten=LEAD

Mega Manunggal Property Tbk PT https://www.idx.co.id/perusahaantercatat/profil-perusahaantercatat/detail-profile-perusahaantercatat/?kodeEmiten=MMLP

Nalarreason, Kadek Marlina, Sutrisno T, and Endang Mardiati. 2019. "Impact of Leverage and Firm Size on Earnings Management in Indonesia." International Journal of Multicultural and Multireligious Understanding 6(1): 19.

Nafiah, Zumrotun. (2013). "Manajemen 
Laba Ditinjau Dari Sudut Pandang Praktisi dan Akademisi". Jurnal Stie Semarang, Vol 5(2).

Natalia, Dessy. (2013). "Analisis Pengaruh Wajibnya Penerapan Good Corporate Governance Terhadap Biaya Ekuitas Pada Badan Usaha Milik Negara Yang Terdaftar Di Bursa Efek Indonesia Tahun 2009-2012". Skripsi: Bina Nusantara.

Nippon Corpindo Tbk PT https://www.idx.co.id/perusahaantercatat/profil-perusahaantercatat/detail-profile-perusahaantercatat/?kodeEmiten=ROTI

Otoritas Jasa Keuangan. (2019). Index Member Profiles IDX LQ45 period of August 2019 - January 2020. August. http://www.idx.co.id/media/2462/201 70426_idx-lq45-february 2017.pdf

Pahmi, A. R. (2018). Pengaruh Profitabilitas, Leverage, Struktur Modal, Ukuran Perusahaan, Dan Earning Power Terhadap Manajemen Laba. 1-122.

Panca Global Securities Tbk PT https://www.idx.co.id/perusahaantercatat/profil-perusahaantercatat/detail-profile-perusahaantercatat/?kodeEmiten=PEGE

Pasaribu, Topowijono dan Sri. (2016). "Pengaruh Struktur Modal, Stuktur Kepemilikan dan Profitabilitas Terhadap Nilai Perusahaan Pada Perusahaan Sektor Industri Dasar dan Kimia Yang Terdaftar di BEI Tahun 2011 - 2014". Jurnal Administrasi Bisnis (JAB). Vol. 35. No 1. Hal $154-$ 164.

Pembangunan Perumahan Persero Tbk PT https://www.idx.co.id/perusahaantercatat/profil-perusahaantercatat/detail-profile-perusahaantercatat/?kodeEmiten $=$ PPRG

Purnomo, B., S., \& Pratiwi, P. (2009). "Pengaruh Earning Power Terhadap Praktek Manajemen Laba (Earning Management) (Suatu Kasus Pada Perusahaan Go Public Sektor Manufaktur)". Jurnal Media Ekonomi,
Vol.14 No.1

Idx. (2021). "Profil Perusahaan Tercatat." Bursa Efek Indonesia. https://www.idx.co.id/perusahaantercatat/profil-perusahaan-tercatat/

Rahyuningsih \& Sri Ayem. (2020). Pengaruh Leverage dan Kepemilikan Manajerial Terhadap Manajemen Laba dengan Agency Cost sebagai Variabel Intervening pada Perusahaan Manufaktur. Jurnal Kajian Bisnis, Vol 28(2).

Ratnawati, V., \& Abdul Hamid, M. A. (2015). The moderating effect of managerial ownership and institutional ownership on the relationship between control right and earnings management. Australian Academy of Acounting and Finance Review, 1(1), 69-85.

Ratu Prabu Energi Tbk PT https://www.idx.co.id/perusahaantercatat/profil-perusahaantercatat/detail-profile-perusahaantercatat/?kodeEmiten $=$ ARTI

Red Planet Indonesia Tbk PT https://www.idx.co.id/perusahaantercatat/profil-perusahaantercatat/detail-profile-perusahaantercatat/?kodeEmiten=PSKT

Ristia Bintang Mahkotasejati Tbk PT https://www.idx.co.id/perusahaantercatat/profil-perusahaantercatat/detail-profile-perusahaantercatat/?kodeEmiten=RBMS

Riyanto, Bambang. (2008). Dasar-Dasar Pembelanjaan Perusahaan Edisi Keempat. Yogyakarta: BPFE

Sandyaswari, Ni Putu, and Gerianta Wirawan Yasa. 2016. "Indikasi Manajemen Laba Pada Perusahaan Yang Melakukan Right Issue Dan Pengaruhnya Terhadap Kinerja Perusahaan." E-Jurnal Akuntansi Universitas Udayana 15(1): 378-406.

Sartono, Agus. (2008). Manajemen Keuangan, Teori dan Aplikasi. Yogyakarta: BPFE

Savitri, Diana dan Denies P. (2019). "Pengaruh Leverage Terhadap 
Manajemen Laba dengan Corporate Social Governance sebagai Variabel Pemoderasi pada Perusahaan Manufaktur Sektor Aneka Industri yang Terdaftar di BEI Periode 20132016". Jurnal Nominal, VIII(2), hal. 179-193.

Schipper, K. (1989). Commentary on Earnings Management. Accounting Horizon, 3 (4: 91 - 102)

Sekar Bumi Tbk PT https://www.idx.co.id/perusahaantercatat/profil-perusahaantercatat/detail-profile-perusahaantercatat/?kodeEmiten $=$ SKBM

Soesetio, Y. (2016). Kepemilikan Manajerial dan Institusional, Kebijakan Dividen, Ukuran Perusahaan, Struktur Aktiva Dan Profitabilitas Terhadap Kebijakan Utang. Jurnal Bisnis dan Akuntansi, Vol 11 No. 3

Solusi Tunas Pratama Tbk PT https://www.idx.co.id/perusahaantercatat/profil-perusahaantercatat/detail-profile-perusahaantercatat/?kodeEmiten $=$ SUPR

Suartama, M. B., \& Sukartha, I. M. (2020). The Effect of Managerial Ownership on Earnings Management of Acquirers on the Indonesia Stock Exchange. American Journal of Humanities and Social Sciences Research, 4(7), 31-34.

Sudana, I Made. (2015). Manajemen Keuangan Perusahaan. Edisi Kedua. Jakarta: Erlangga

Sudiyanto, Yayan and Husaini. (2016). Pengaruh Kepemilikan Institusional, Kepemilikan Manajerial dan Leverage Terhadap Manajemen Laba dan Konsekuensinya Terhadap
Nilai Perusahaan (Studi pada Perusahaan yang Melakukan Right Issue di Bursa Efek Indonesia Periode 2009-2013). Undergraduated thesis.

Sugiyono. (2016). Metode Penelitian Kuantitatif, Kualitatif dan R\&D. Bandung: Alfabeta.

Sugiyono. (2007). Metodologi Penelitian Bisnis, PT. Gramedia, Jakarta.

Sulistyanto, Sri. 2008. Manajemen Laba Teori dan Model Empiris. Jakarta: Grasindo.

Utami, Niken (2016) "Pengaruh leverage, kepemilikan institusional dan kepemilikan manajerial terhadap manajemen laba. Studi empiris di Perusahaan Manufaktur yang terdaftar di Bursa Efek Indonesia periode tahun 2009-2012”. Skripsi thesis: Sanata Dharma University.

Vakilifard, H., \& Mortazavi, M. S. S. (2016). The Impact of Financial Leverage on Accrual-Based and Real Earnings Management. International Journal of Academic Research in Accounting, Finance and Management Sciences, 6(2), 53-60. https://doi.org/10.6007/ijarafms/v6i2/2039

Verena Multifinance Tbk PT https://www.idx.co.id/perusahaantercatat/profil-perusahaantercatat/detail-profile-perusahaantercatat/?kodeEmiten=VRNA

Wijaya Karya Tbk PT https://www.idx.co.id/perusahaantercatat/profil-perusahaantercatat/detail-profile-perusahaantercatat $/$ kodeEmiten $=$ WIKA 